Editorial

\title{
The Feminist Project under Threat in Europe
}

\author{
Mieke Verloo ${ }^{1, *}$ and David Paternotte ${ }^{2}$ \\ ${ }^{1}$ Institute for Management Research, Radboud University, 6525 HP Nijmegen, The Netherlands; E-Mail: m.verloo@fm.ru.nl \\ 2 Department of Social Sciences, Faculty of Philosophy and Social Sciences, Université libre de Bruxelles, 1000 Brussels, \\ Belgium; E-Mail: david.paternotte@ulb.ac.be
}

* Corresponding author

Submitted: 4 September 2018 | Published: 14 September 2018

\begin{abstract}
Is the feminist project under threat in Europe? This thematic issue addresses the question in both theoretical and empirical ways, focusing on the various ways in which feminist politics are opposed and why, on what the impact of such opposition is, and how to improve our theoretical understanding of this particular manifestation of gender and politics. The issue addresses three major challenges: a need to reflect on the most suited concepts and theories in political and social sciences to understand what is at stake in Europe today; a need to vernacularize existing knowledge while forging global frames of analysis; and a need to avoid the risk of reifying oppositional forces and of reiterating dichotomous frames and categories. The responses to these challenges are: to analyse the threats to the feminist project as parts of larger projects against social justice and equality; to contrast macro narratives by engaging with the microlevel of the anti-feminist project, enabling a critique of mainstream scholarship; to analyse the threats to the feminist project as related to processes of changes to democracy, such as democratic backsliding; to give prominent attention to discursive, epistemic and symbolic processes; and finally to include studies on the response of feminist actors to the threats experienced. This collection of articles offers a variety of perspectives on the various threats to the feminist project in Europe today.
\end{abstract}

\section{Keywords}

abortion politics; anti-gender campaigns; democratic backsliding; discursive politics; Europe; feminism; LGBT politics; opposition; populism; sexual politics

Issue

This editorial is the introduction to the Thematic Issue "The Feminist Project under Threat in Europe", edited by Mieke Verloo (Radboud University, The Netherlands) and David Paternotte (Université libre de Bruxelles, Belgium).

(C) 2018 by the authors; licensee Cogitatio (Lisbon, Portugal). This article is licensed under a Creative Commons Attribution 4.0 International License (CC BY).

Is the feminist project under threat in Europe? Asking this question at the beginning of 2018-when we planned this thematic issue-was a rather rhetorical question, but by the end of 2018, the answer is more and more unequivocally positive. Opposition to feminist and sexual politics-even if a staple of politics in many times and places-has become more visible in Europe, and can now be found at national, regional and international level, and involves different kinds of actors and mechanisms. This new situation is characterized by a double phenomenon: an increasing polarization in politics and an increased politicization of gender and sexuality, leading to new forms of opposition and changing alliances between oppositional actors. Given these changes, this thematic issue addresses the question in both theoretical and empirical ways. It focuses on the various ways in which feminist politics and gender equality policies are opposed and why, on what the impact of such opposition is, and how to improve our theoretical understanding of this particular manifestation of gender and politics.

By using the term "project", we build on Sylvia Walby's scholarship and regard feminism as "a set of processes and practices in civil society that create new meanings and social goals, drawing on a range of rhetorical and material resources" (Walby, 2011, p. 6). This allows us to widen the understanding of what constitutes a social 
movement and not to restrict it to a particular ideology, to particular activities or to relatively stabilized and institutionalized groups and practices. The feminist project includes therefore a wider and more diverse set of ideas, actors and practices, as long as these can be described as "having a general objective directed at changing society and some actors and activities trying to make that happen" (Walby, 2011). As made clear in several contributions, this also makes room for the internal diversity of feminism(s), and acknowledges that it has historically been characterized by tensions, controversies and debates (see also Kantola \& Verloo, 2018).

In Europe, various events such as massive demonstrations against same-sex marriage or the Istanbul Convention, attempts to restrict access to abortion or sex education and the electoral victories of antifeminist political parties have opened the eyes of the academic community, and research is progressively catching up. Indeed, scholars, who were often influenced by modernization theories, long assumed-at least implicitly-that oppositions would simply disappear over time, and did therefore not deserve thorough academic investigation. They also regarded their limited impact on policy making as further evidence of their irrelevance. Furthermore, the scarce scholarship on opposition was generally restricted to specific geographic areas such as Eastern or Southern Europe, and decades of European optimism combined with a vigorous faith in the positive effects of Europeanization led some scholars to assume that the advent of the European project would inevitably strengthen feminist and LGBT equalities in the region (Ayoub \& Paternotte, 2014; Lombardo \& Forest, 2012). Elsewhere, the rise of homo- and femonationalisms (e.g., Bracke, 2012; Farris, 2017; Mepschen, Duyvendak, \& Tonkens, 2010) was sometimes interpreted as the evidence of the irresistible although distorted progress of emancipatory projects, while shifting the focus away from "traditional" religious and political oppositions.

In brief, for most students of gender and sexuality politics in Europe, things could only get better, including in hostile settings. As a result, unlike in the United States, where the strength of the Christian right had inspired a wide scholarship (e.g., Fetner, 2008; Staggenborg, 1994; Stone, 2012), the oppositions and resistances to gender and sexual equality were largely understudied in Europe and researchers preferred to accompany and theorize social and political change, while collaborating with stakeholders to improve policy-making.

In recent years, the academic landscape has indubitably altered, as testified by the emergence of a literature that gradually fills major research gaps (e.g., Agrikoliansky \& Collovald, 2014; Avanza \& Della Sudda, 2017; Bracke \& Paternotte, 2016; Broqua \& Fillieule, 2018; Garbagnoli \& Prearo, 2017; Graff \& Korolczuk, 2018; Graff, Kapur, \& Walters, in press; Gutiérrez Rodríguez, Tuzcu, \& Winkel, 2018; Gutsche, 2018; Hark \& Villa, 2015; Köttig, Bitzan, \& Petö, 2017; Kovats \& Pooim, 2015; Kuhar, 2015; Kuhar \& Paternotte, 2017; Lom- bardo \& Mergaert, 2013; Paternotte, van der Dussen, \& Piette, 2016; Roth, 2018; Scrinzi, 2014; Spierings, Zaslove, Mugge, \& de Lange, 2015; Verloo, 2018a). However, while these studies document and analyse recent opposition, there is still a strong lack of more conceptual and theoretical contributions. This thematic issue moves one step forward by bringing together different research networks within the gender and politics community, and by addressing conceptual and methodological challenges crucial to a further consolidation of the field. Three of them deserve a more thorough discussion in this editorial.

First, a deeper reflection on how we approach these oppositional dynamics is needed. This implies at least two steps, as illustrated by the various articles in this thematic issue (see Paternotte \& Kuhar, 2018; Verloo, 2018b; Walby, 2018; but also Krizsan \& Roggeband, 2018; Meier \& Severs, 2018). On the one hand, it is urgent to reflect on the most suited concepts to understand what is at stake in Europe today. In other words, we do not only need good empirics, but also a discussion of the promises and the limitations of our concepts and perspectives. On the other hand, we have to identify the approaches and theories in political and social sciences that are likely to help us shed some light on current developments, as well as the debates in which we want to locate our scholarship. This endeavor allows scholars to distance themselves from everyday understandings of the current situation, which are often obscured by underlying values and a sense of emergency. Echoing public debates, academic discussions should avoid as much as possible to judge or ridicule, both implicitly and explicitly, the actors and the dynamics under study. They should not be obscured by the apocalyptic account of a world falling apart and nostalgic longings for the "world of yesterday" - not to say a fascination for the power of dystopias (Segal, 2017). Having said this, we do not aim to condemn researchers' public involvement or political positioning, but to warn them against the unexpected distortions ensuing from the use of specific glasses.

Second, we need to vernacularize existing knowledge while forging global frames of analysis. As mentioned earlier, the development of a field on oppositional politics in the United States has closely followed the successes of the religious right, leading to notions and approaches such as culture wars, morality politics, or the movements/counter-movements dynamics. While these have long demonstrated their analytical value, we need to reflect on the way such concepts and approaches travel across the Ocean and whether they are best suited to examine current developments in Europe. This implies investigating whether these concepts and approaches are conditioned by the specific trajectory of the context for which they were imagined (e.g., Engeli, GreenPedersen, \& Thorup Larsen, 2012; Mondo, 2018; Ozzano \& Giorgi, 2015), as well as determining what they allow us to grasp, and unpacking the specific narratives to which research participates. While context clearly mat- 
ters, we observe an increasing transnationalisation and globalisation of oppositional actors and dynamics (e. g., Corrêa, Paternotte, \& Kuhar, 2018), which urges us to move away from methodological nationalism and European exceptionalism. As a result, instead of promoting vague and catch-all categories such as "populism" or "global right" or even "democracy", or assuming a mere export of US oppositional dynamics, we need to invent new analytical frames or amend existing ones that allow us to apprehend transnational and global trends while accounting for local specificities and acknowledging the agency of local actors.

Third, current research runs the risk of reifying oppositional forces and of reiterating dichotomous frames and categories, which are often modeled after the canonical opposition between "us and them". This applies to both "camps", as feminism as well as other so-called progressive forces can be homogenized in problematic ways, and crucial tensions and divisions characterizing their "enemies" can be overlooked. We have to avoid being dragged into the increasing division of political actors along the binary lines opposing liberals to populists, while still keeping a clear vision on what is truly dangerous for the feminist project, or for other equality and social justice projects.

To conclude, aside from much needed empirical case studies, this thematic issue offers a wealth of conceptual and theoretical reflections on how to best understand what is happening. It sheds new light on established fields such as democratization studies or right-wing politics, and further confirms the importance of adopting a gendered lens, an insight often overlooked by leading scholars in the field (Krizsan \& Roggeband, 2018; Norocel, 2013).

In response to the three challenges described above: the need for better conceptualization, the need for more vernacularization and the importance of overcoming us versus them studies, this thematic issue offers five responses.

First, it analyzes the threats to the feminist project as parts of larger political projects against social justice and equality, driven by very different actors such as those linked to the Catholic Church, those that are part of the extreme right in Europe and beyond, but also those that hide under the seemingly more neutral cover of neoliberalism. Especially the articles by Alonso and Lombardo (2018), Kuhar and Paternotte (2018), Krizsan and Roggeband (2018) and Walby (2018) have much to offer here. This perspective is especially valuable in that it displaces the US based scholarship by contextualizing the European case. It also invites us to examine how different and sometimes competing projects can be combined instead of lumping them together (as Verloo, 2018, examines in showing how opposition to feminism and to science is linked for instance).

Second, it contrasts macro narratives by engaging with the microlevel of the anti-feminist project, enabling a critique of mainstream social movement scholarship.
Avanza (2018) in this issue provides a much-needed study of this micro-level of the anti-abortion movement in Italy. Verloo (2018) zooms in more closely at the actual voting behavior of an extreme-right party in the Netherlands. Meier and Severs (2018), as well as Norocel (2018), give new data but also a new conceptualization of practices of far-right politicians in Belgium, Hungary and Romania.

Third, it analyzes the threats to the feminist project as related very deeply to processes of changes to democracy in Europe, such as democratic backsliding and de-democratization. This perspective can profoundly change and improve scholarship on gender and democracy. There are several articles contributing in this line of response: Alonso and Lombardo (2018), Krizsan and Roggeband (2018) and Miškovska Kajevska (2018) in particular.

Fourth, this thematic issue gives prominent attention to discursive, epistemic and symbolic processes. The focus on episteme as a theoretical concept expands a narrower study of gender to include also the production of knowledge and truth in societies (Verloo, 2018b). This particular line of response also highlights the role of politicians, and in doing so, asks new questions about the performance of gender in politics, about the link between discursive and material positions taken by politicians, and about symbolical representation (see especially Meier \& Severs, 2018, for this, as well as Norocel, 2018).

Finally, several articles include the response of feminist actors to the threat they experience. Both Aksoy (2018) and Krizsan and Roggeband (2018) shed light on the resistance by feminist forces and examine how the actors under attack are mobilizing.

In conclusion, in this thematic issue, we are not providing a single and consistent framework, but offering a variety of perspectives which illuminate and reflect on the various threats to the feminist project in Europe today. While it is also worthwhile to develop an encompassing frame that would host these various phenomena under the same roof (see Verloo, 2018a, for an example of that), we prefer here not to hide the tensions and oppositions between articles, in order to show the vitality of this new field of research. The contributions in this thematic issue raise a set of questions which are crucial to the further development of the field (next to highlighting the urgent need for more empirical studies): what are the epistemic and analytical effects of specific concepts and approaches on the knowledge we produce? What do they allow us to see and do they obscure our analysis? How politics and research are mutually intertwined and how do they affect each other? How categories elaborated elsewhere can travel to Europe and other contexts? Can a literature forged to study other difficult times in European history help us understand what is happening nowadays? What is our role and our responsibility as scholars in Europe today, when significant parts of the region are rapidly moving towards more authoritarian regimes? 


\section{Acknowledgments}

The authors thank the Editor and anonymous reviewers for their helpful comments and suggestions.

\section{Conflict of Interests}

The authors declare no conflict of interests.

\section{References}

Agrikoliansky, E., \& Collovald, A. (Eds.). (2014). Mobilisations conservatrices [Conservative mobilizations]. Politix, 106.

Aksoy, H. A. (2018). Gendered strategies between democratization and democratic reversal: The curious case of Turkey. Politics and Governance, 6(3), 101-111.

Alonso, A., \& Lombardo, E. (2018). Gender equality and de-democratization processes: The case of Spain. Politics and Governance, 6(3), 78-89.

Ayoub, P. M., \& Paternotte, D. (Eds.). (2014). LGBT activism and the making of Europe: A rainbow Europe? Basingstoke: Palgrave.

Avanza, M. (2018). Plea for an emic approach towards "ugly movements": Lessons from the conflicts within the Italian pro-life movement. Politics and Governance, 6(3), 112-125.

Avanza, M., \& Della Sudda, M. (Eds.). (2017). Ripostes catholiques [Catholics responses]. Genre, sexualité, société, 18.

Bracke, S. (2012). From "saving women" to "saving gays": rescue narratives and their discontinuities. European Journal of Women's Studies, 19(2), 237-252.

Bracke, S., \& Paternotte, D. (Eds.) (2016). Habemus gender. The Catholic Church and "gender ideology". Religion \& Gender, 6(2).

Broqua, C., \& Fillieule, O. (Eds.). (in press). Sexuality and opposing movements. Social Movement Studies.

Corrêa, S., Paternotte, D., \& Kuhar, R. (2018, May 11). The globalization of anti-gender campaigns. International Politics and Society. Retrieved from http://www. ips-journal.eu/topics/human-rights/article/show/the -globalisation-of-anti-gender-campaigns-2761

Engeli, I., Green-Pedersen, C., \& Thorup Larsen, L. (Eds.). (2012). Morality politics in western Europe: Parties, agendas and policy choices. Basingstoke: Palgrave MacMillan.

Farris, S. (2017). In the name of women's rights: The rise of femonationalism. Durham: Duke University Press.

Fetner, T. (2008). How the religious right shaped lesbian and gay activism. Minneapolis, MN: University of Minnesota Press.

Garbagnoli, S., \& Prearo, M. (2017). La croisade antigenre [The anti-gender crusade]. Paris: Textuel.

Graff, A., \& Korolczuk, E. (2018). Gender as "Ebola from Brussels": The anti-colonial frame and the rise of illiberal populism. Signs, Journal of Women in Culture and Society, 43(4), 797-821.
Graff, A., Kapur, R., \& Danuta Walters, S. (Eds.). (in press). Gender and the rise of the global right. Signs, Journal of Women in Culture and Society.

Gutiérrez Rodríguez, E., Tuzcu, P., \& Winkel, H. (Eds.). (2018). Special section on feminisms in times of antigenderism, racism and austerity. Women's Studies International Forum, 68.

Gutsche, E. (Ed.). (2018). Triumph of the women? The female face of the populist \& far right in Europe. Berlin: Friedrich-Ebert-Stiftung.

Hark, S., \& Villa, P.-I. (Eds.). (2015). (Anti-)genderismus. sexualität und geschlecht als sch auplätze aktueller politischer auseinandersetzungen [Anti-genderism, sexuality and gender as showcases of recent political debates]. Bielefeld: Transcript.

Kantola, J., \& Verloo, M. (2018). Revisiting gender equality at times of recession: A discussion of the strategies of gender and politics scholarship for dealing with equality. European Journal of Politics and Gender, 1(1/2), 205-222.

Köttig, M., Bitzan, R., \& Pető, A. (Eds.). (2017). Gender and far right politics in Europe. Basingstoke: Palgrave Macmillan.

Kováts, E., \& Põim, M. (Eds.). (2015). Gender as symbolic glue: The position and role of conservative and far right parties in the anti-gender mobilization in Europe. Brussels: Foundation for European Progressive Studies and Friedrich-Ebert-Stiftung Budapest.

Krizsan, A., \& Roggeband, C. (2018). Towards a conceptual framework for struggles over democracy in backsliding states: Gender equality policy in Central Eastern Europe. Politics and Governance, 6(3), 90-100.

Kuhar, R. (2015). Playing with science: Sexual citizenship and the Roman Catholic Church counter-narratives in Slovenia and Croatia. Women's Studies International Forum, 49(1), 84-92.

Kuhar, R., \& Paternotte, D. (Eds.). (2017). Anti-gender campaigns in Europe. Mobilizations against equality. London: Rowman \& Littlefield.

Lombardo, E., \& Mergaert, L. (2013). Gender mainstreaming and resistance to gender training: A framework for studying implementation. NORA-Nordic Journal of Feminist and Gender Research, 21(4), 296-311.

Lombardo, E., \& Forest, M. (Eds.). (2012). The Europeanization of gender equality policies: $A$ discursive-sociological approach. Basingstoke: Palgrave Macmillan.

Meier, P., \& Severs, E. (2018). The dark side of descriptive representation: Bodies, normalisation and exclusion. Politics and Governance, 6(3), 31-42.

Mepschen, P., Duyvendak, J. W., \& Tonkens, E. (2010). Sexual politics, orientalism and multicultural citizenship in the Netherlands. Sociology, 44(5), 962-979.

Miškovska Kajevska, A. (2018). A foe of democracy, gender and sexual equality in Macedonia: The worrisome role of the party VMRO-DPMNE. Politics and Governance, 6(3), 55-66. 
Mondo, E. (2018). European culture wars? Abortion and human embryonic stem research (1998-2015) (Unpublished Doctoral Dissertation). Université Libre de Bruxelles, Brussels, Belgium.

Norocel, C. O. (2013). Our people-A tight-knit family under the same protective roof: A critical study of gendered conceptual metaphors at work in radical right populism. (Unpublished Doctoral Dissertation). University of Helsinki, Helsinki, Finland.

Norocel, C. O. (2018). Antifeminist and "truly liberated": Conservative performances of gender by women politicians in Hungary and Romania. Politics and Governance, 6(3), 43-54.

Ozzano, L., \& Giorgi, A. (2015). European culture wars and the Italian case: On which side are you on? London: Routledge.

Paternotte, D., \& Kuhar, R. (2018). Disentangling and locating the "global right": Anti-gender campaigns in Europe. Politics and Governance, 6(3), 6-19.

Paternotte, D., van der Dussen, S., \& Piette, V. (2016). Habemus gender! Déconstruction d'une riposte religieuse [Habemus gender! Deconstruction of a religious response]]. Brussels: Editions de l'Université de Bruxelles.

Roth, S. (Ed.). (2018). Rapid response-Contemporary counter-movements in the age of Brexit and Trump.
Sociological Research Online, 23(2), 232-241.

Scrinzi, F. (2014). Caring for the nation: Men and women activists in radical right populist parties 2012-2014 (Final Research Report to European Research Council). Glasgow: University of Glasgow.

Spierings, N., Zaslove, A., Mugge, L. M., \& de Lange, S. L. (2015). Gender and populist radical-right politics: An introduction. Patterns of Prejudice, 49(1/2), 3-15.

Segal, L. (2017). Radical happiness: Moments of collective joy. London: Verso.

Staggenborg, S. (1994). The pro-choice movement: Organization and activism in the abortion conflict. Oxford: Oxford University Press.

Stone, A. (2012). Gay rights at the ballot box. Minneapolis, MN: University of Minnesota Press.

Verloo, M. (Ed.). (2018a). Varieties of opposition to gender equality in Europe. London: Routledge.

Verloo, M. (2018b). Gender knowledge, and opposition to the feminist project: Extreme-right populist parties in the Netherlands. Politics and Governance, 6(3), 20-30.

Walby, S. (2011). The future of feminism. Cambridge: Polity.

Walby, S. (2018). Is Europe cascading into fascism? Addressing key concepts including gender and violence. Politics and Governance, 6(3), 67-77.

\section{About the Authors}

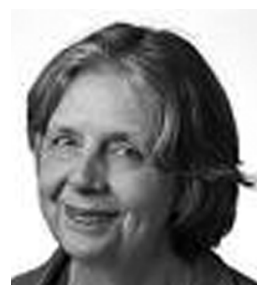

Mieke Verloo is Professor of Comparative Politics and Inequality Issues at Radboud University in the Netherlands, and Non-Residential Permanent Fellow at the IWM, Institute for Human Sciences in Vienna. She is the winner of the 2015 ECPG Gender and Politics Career Achievement Award. She edited Varieties of Opposition to Gender Equality in Europe, published by Routledge (2018). Her recent work is on the complex relationship between democracy and gender+ equality.

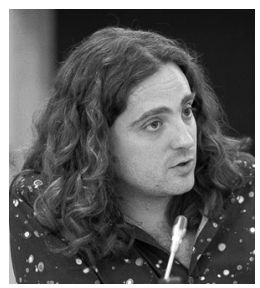

David Paternotte is Associate Professor in Sociology and Gender Studies at the Universite libre de Bruxelles, where he is the head of the Atelier Genre (s) et Sexualite (s) and STRIGES. His publications include the monograph Revendiquer le "Mariage Gay": Belgique, France, Espagne (2011), numerous articles, chapters and edited volumes, including Anti-Gender Campaigns in Europe: Mobilizing against Equality (2017). He is a co-editor of the series "Global Queer Politics" (Palgrave). 